\title{
Tarihsel Eleştiri ve Kutsal Metnin Otoritesi: 17. ve 18. Yüzyılda Kutsal Kitap Eleştirisi ile Metne Sadakat Arasındaki Gerilim üzerine Bir İnceleme
}

Araştırma makalesi / Research article

Asim DURAN*

Historical Criticism and the Authority of Scripture: A Study on the Tension Between Biblical Criticism and Faithfulness to the Scripture in the $17^{\text {th }}$ and $18^{\text {th }}$ Centuries

Citation/@): Duran, Asim, (2019). Historical Criticism and the Authority of Scripture: A Study on the Tension Between Biblical Criticism and Faithfulness to the Scripture in the $17^{\text {th }}$ and $18^{\text {th }}$ Centuries, Milel ve Nihal, 16 (2), 305-329.

Abstract: This article focuses on the tension between critical studies and faithfulness to the Scripture rather than the findings of historical criticism in the seventeenth and eighteenth centuries. In this context, the dimensions of the relationship between historical-critical studies and the authority of the Scripture are discussed in the article. In the paper, it is assumed that the major critics of this period did not largely reject the authority of the Scripture, but rather they tried to provide with a different authority as a problem of harmony within the modern culture in the face of critical studies. In this context, it is aimed to show what kind of theology did they develop, which tries to make a connection between faith and the Bible and the findings of modern biblical studies. Therefore, although the article is directly about the Bible, it is indirectly important for it contains possible clues about the content of the discussions about the authority of the Hadiths in the Muslim world.

Keywords: Historical Criticism, Bible, Biblical Authority, Biblical Criticism.

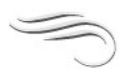

* Dr. Öğr. Üyesi, Ordu Üniversitesi, İlahiyat Fakültesi, Din Bilimleri Anabilim Dalı [asimduran@odu.edu.tr] ORCID: 0000-0003-2153-8451. 
Atıf/C: Duran, Asim, (2019). Tarihsel Eleştiri ve Kutsal Metnin Otoritesi: 17. ve 18. Yüzyılda Kutsal Kitap Eleştirisi ile Metne Sadakat Arasındaki Gerilim Üzerine Bir İnceleme, Milel ve Nihal, 16 (2), 305-329.

Öz: Bu makale, on yedinci ve on sekizinci yüzyılda tarihsel eleştirinin verilerine değil, bu dönemlerdeki eleştirel çalışmalar ile metne sadakat arasındaki gerilime odaklanmaktadır. Bu bağlamda yazıda, tarihsel-eleştirel çalışmalar ile kutsal metnin otoritesi arasındaki ilişkinin boyutları ele alınmaktadır. Makalede dönemin önemli eleştirmenlerinin kutsal metnin otoritesini büyük oranda reddetmedikleri, bilakis eleştirel bilim karşısında otoritesi sarsılan metne, modern kültür içinde bir uyum sorunu olarak farklı bir otorite sağlamaya çalıştıkları varsayılmaktadır. Bu bağlamda ilgili ilahiyatçıIarın inanç ve kutsal metin ile modern eleştirilerin verileri arasında bağ kurmaya çalışan nasıl bir teoloji geliştirdiklerini göstermek amaçlanmaktadır. Bu yüzden makale, her ne kadar doğrudan Kitab-ı Mukaddes üzerine olsa bile, dolaylı bir biçimde son dönem İslam dünyasında hadislerin otoritesine dair tartışmaların içeriği konusunda muhtemel ipuçları barındırması dolayısıyla önem arz etmektedir. İslam dünyasında hadislerin geleneksel otoritesine dair tartışmalara aşina olan bir okur, bu tür tartışmaların Kitabı-ı Mukaddes ile benzerliğini fark etmekte zorlanmayacaktır.

Anahtar Kelimeler: Tarihsel Eleştiri, Kitab-ı Mukaddes, Kutsal Kitabın Otoritesi, Kutsal Kitap Eleştirisi.

\section{Giriş}

Kutsal kitap eleştirisi tarihçileri, Hıristiyan dünyada Kitab-1 Mukaddes'in hem manevi-metafizik hem de tarihi gerçekleri ifade eden doğaüstü bir metin olarak anlaşılmasının, post-Aydınlanma döneminde yükselişe geçen tarihsel-eleştirel çalışmalardan yıkıcı saldırılar aldığ1 konusunda neredeyse hemfikirdir. Bir tarafta muhafazakârlar diğer tarafta ise eleştirel bilim taraftarları, kutsal metin araştırmalarında popüler bir yönelim olarak gelişen bu durumun kutsal kitabın otoritesiyle doğrudan bağlantılı olduğunu fark etmede gecikmediler. Protestan evanjelikler, Katolik Kilise taraftarları ve kendini muhafazakâr düşünme tarzı içinde konumlandıran diğer gruplar ile liberal eleştirmenler arasında öteden beri süregelen tartışmalar bunu doğrulamaktadır. ${ }^{1}$ Bu yüzden modern tarihsel-eleşti-

1 Makale boyunca yer yer kullanılan 'muhafazakâr' ve 'liberal' kavramları, siyasal literatürün dışında ve sadece kutsal kitap araştırmaları karşısında alınan iki farklı pozisyonun prototipine işaret etmek için kullanılmıştır. Buna göre, muhafazakârlar ifadesiyle kutsal metnin geleneksel otoritesini kabul eden ve eleştirel bilime kuşkuyla yaklaşan ilahiyatçlar kastedilmiştir. Liberaller ifadesiyle ise modern kutsal kitap eleştirilerinin verilerine güvenen ve böylece eleştirel süreci 
rel çalışmalarla kutsal metin arasındaki gerilim sorunu, esasında konuya kısmen de olsa ilgi duyan kimseler için gizli değildir. Bilhassa modern tarihsel-eleştirel çalışmaların kutsal kitap dışı (nonbiblical) verilerinin Hıristiyan inananların kutsal metinle olan ilişkilerini yeniden belirlediğine dair inanç, kutsal metnin otoritesi konusunda yeniden düşünmeye sevk etti. Öyle anlaşılıyor ki bu dönemde muhafazakârlar bir yana eleştirel bilim taraftarları dahi, eleştirel çalışmaların verileri ile geleneksel inancın korunması arasında kendilerini sıkışmış hissettiler.

Kimi araştırmacıların daha önce fark ettiği üzere Hıristiyan dünyada tarihsel eleştirinin yaklaşık üç yüzyıllık serüveni boyunca karşı karşıya kalınan belki de en temel sorunlarından biri şuydu: Şayet kutsal kitap, tarihsel olarak yanlış bilgiler içeriyorsa ve onda dile getirilen anlatıların tarihsel doğruluğu literal olarak sorgulanabilir nitelikteyse o zaman böyle bir metnin (dolayısıyla vahyin) kesinliği ve manevi değeri de şüphe altına girecektir. Çünkü geleneksel H1ristiyan inancı büyük oranda kutsal metindeki bu tarihsel hadiselerden beslenmektedir. Dahası peygamberler ve onlarla ilişkili mucizelerle ilgili anlatılar, Kitab-1 Mukaddes'te önemli yer tutmaktadır. Şu hâlde herhangi bir tarihsel ve arkeolojik çalışma bunların yanlışlığını ortaya koyan bir içerikle yorumlanırsa, o zaman kutsal kitaba olan inanç ve sadakat nasıl değerlendirilecektir? Söz gelimi, inanç geleneksel geçerliliğini koruyabilecek midir? Yine şayet, kutsal metin antik dönemde Bereketli Hilal'de meydana gelen tek yönlü bir dini yönelimin yazılı birikimi ise sadece, bu durumda başka dini geleneklerin sahip olmadığ Bu bağlamda kutsal metnin yegâne ilahi otorite olduğu iddiası nasıl

\footnotetext{
daha da ileriye götürmeye çalışan tarihçilere/teologlara işaret edilmiştir. Hem muhafazakârların hem de eleştirel bilim taraftarlarının kutsal metne yönelik tutumlarının genel bir değerlendirmesi için Bk. Christopher M. Hays, "Towards a Faithful Criticism", Evangelical Faith and the Challenge of Historical Criticism, ed. Christopher M. Hays ve Christopher B. Ansberry (Grand Rapids: Baker Academic, 2013), 1-23. Ayrica liberaller ile daha radikal teolojiler arasında bu bağlamda yapılan tartışmaların genel içeriği için bk. Paul E. Capetz, "Theology and the Historical-Critical Study of the Bible", The Harvard Theological Review 104/4 (2011): 459-488; Robert M. Price, Inerrant the Wind: Evangelical Crisis of Biblical Authority (Amherst, New York: Prometheus Books, 2009), 13-60. Mark Noll ise on dokuzuncu yüzyılın sonlarında Amerika'da ve İngiltere'de tarihsel eleştiriye dair muhafazakâr tutumların bir portresini çıkarmaya çalışmıştır. Bk. Mark A. Noll, Between Faith and Criticism: Evangelicals, Scholarship, and the Bible in America (Vancouver: Regent College Publishing, 2004), 11-90.
} 
ele alınacaktır? Tarihin görecelikleri içerisine dalmış bir vahiy, sonunda nasıl oluyor da otoriter bir vahiy olabiliyor veya olduğu söylenebiliyor? Tüm bunların ötesinde kutsal metnin otoritesi, onun kaynağ maların ışı̆̆ında hala nasıl devam ettirilebilir? ${ }^{2}$

Kabaca aktardığımız bu sorunlar, kutsal metinlere yönelik modern tarihsel-eleştirel çalışmaların verileriyle yüzleşmek zorunda kalan Hıristiyan dünyanın bir şekilde çözmek zorunda kaldıkları sorunlard1. Bu anlamda kutsal kitap eleştirileri (biblical criticism), en basit haliyle bilimsel meraktan beslenmiş ve entelektüel çabayla motive edilmiş olsa da en nihayetinde Yahudi ve Hiristiyan dünyanın kendi kutsal kitaplarıyla süregelen ilişki biçimlerini yeniden sorgulamalarına yol açtı. Bu yüzden devamında ortaya çıkan sürecin geleneksel vahiy anlayışı (otorite) ile imanın sorgulanmasıyla sonuçlanan bir süreci doğurması tesadüf değildir. Kuşkusuz muhafazakârlar bu tür sorunların nasıl ele alınması gerektiği konusunda boğuşurken, eleştirel bilim taraftarları ise büyük şevkle taraf oldukları bilimsel bulguların kendi geleneksel inançlarını ve kutsal metne sadakatlerini nasıl yönlendireceği konusunda ikilemde kaldılar. Bu tarz bir ikilem ve ortaya çıkan gerilim, kabaca on yedinci yüzyıldan itibaren kutsal kitap eleştirmenlerinin belki de yüz yüze kaldıkları en temel problemlerden biriydi. Bu gerilim sorunu günümüzde de hala devam etmektedir. ${ }^{3}$ Aşağıda kutsal metin eleştirisi tarihinin

2 Gerhard Maier, The End of the Historical-Critical Method (Concordia Publishing House, 1977), 19-21; Alan Richardson, "The Rise of Modern Biblical Scholarship and Recent Discussion of the Authority of the Bible", The Cambridge History of the Bible: The West from the Reformation to the Present Day, ed. S. L. Greenslade (Cambridge: Cambridge University Press, 1976), 296, 304; Peter H. Davids, “Authority, Hermeneutics, and Criticism", New Testament Criticism and Interpretation, ed. David Alan Black ve David S. Dockery (Michigan: Zondervan Pub. House, 1991), 27; Eta Linnemann, "Historical-Critical Theology and Evangelical Theory", Journal of the Adventist Theological Society 5/2 (Bahar 1994): 19-20.

3 Söz gelimi son yüzyılda Protestan çevreler, 'Hıristiyan inancına bağlı ve yapıcı bir eleştiri nasıl yapılabilir' sorunu üzerinde durmaktadırlar. Bk. Kenton L. Sparks, God's Word in Human Words: An Evangelical Appropriation of Critical Biblical Scholarship (Grand Rapids: Baker Academic, 2008). Öte yandan Katolik Kilise, Divino Afflante Spiritu (1945) ve Dei Verbum (1965) genelgeleriyle tarihsel-eleştirel çalışmaların en azından Kiliseye hizmet amacıyla kullanılabileceğini kabul etmiştir. Bk. Joseph A. Fitzmyer, The Interpretation of Scripture: In Defense of the Historical-Critical Method (New York: Paulist Press, 2008), 37-58. Bu yüzden Katolik ve Anglikan çevrelerde de benzer ilgiler ve tartışmalar görülebilir. Bk. A.K.M. Adam, Faithful Interpretation: Reading the Bible in a Postmodern World (Minneapolis: Fortress Press, 2006). 
önemli bazı isimleri üzerinden gösterilmeye çalışılacağı üzere birçok eleştirmen, bu ikilemi aşmak ve eleştirel bilimin yeni sonuçlarryla kutsal metnin otoritesi arasındaki gerilimi azaltmak için bir tür uyum teolojisine başvurmuştur.

Bu makale, on yedinci ve on sekizinci yüzyllda tarihsel eleştirinin verilerine değil; bu dönemlerdeki Katolik ve Protestan merkezli eleştirel çalışmalar ile metne sadakat arasındaki gerilime ve bu bağlamda ortaya çıkan kutsal metnin otoritesindeki dönüşüme odaklanmaktadır. Makalede dönemin önemli eleştirmenlerinin kutsal metnin otoritesini büyük oranda reddetmedikleri, bilakis eleştirel bilim karşısında otoritesi sarsılan metne modern kültür içinde bir uyum sorunu olarak farklı bir otorite sağlamaya çalıştıkları varsayılmaktadır. Bu bağlamda Katolik ve Protestan ilahiyatçıların inanç ve kutsal metin ile modern eleştirilerin verileri arasında bağ kurmaya çalışan nasıl bir teoloji geliştirdiklerini göstermek amaçlanmaktadır. Bu yüzden makale, her ne kadar doğrudan Kitab-1 Mukaddes üzerine olsa bile, dolaylı bir biçimde son dönem İslam dünyasında Kur'an ve hadislerin otoritesine dair tartışmaların içeriği konusunda muhtemel ipuçları barındırması dolayısıyla önem arz etmektedir. İslam dünyasında Kur'an ve hadislerin geleneksel otoritesine dair tartışmalara aşina olan bir okur, bu tür tartışmaların Kitabı-1 Mukaddes ile benzerliğini fark etmede zorlanmayacaktır.

Şu hâlde, modern tarihsel-eleştirel çalışmalarla kutsal metnin otoritesi arasında nasıl bir ilişki bulunmaktadır? Post-Aydınlanma döneminde eleştirel yorumcular, bir uyum sorunu olarak kutsal metin ile ne tür bir ilişki düzeyi kurdular? Modern eleştirel çalışmaların gölgesi altında kutsal metnin otoritesi nasıl devam ettirilmeye çalışılmıştır? Dönemin belli başlı eleştirmenleri üzerinden bunun örnekleri gösterilebilir mi?

\section{Yorumda Otoritenin Değişimi: Tarihsel Eleştirinin Yükselişi}

Hıristiyan dünyada esas itibariyle hem Katolik Kilisenin gözetimi altında hem de Reformasyon'un Sola Scriptura prensibi bağlamında kutsal metin, her bakımdan otoriter bir metin olarak kabul edilmiştir. Gerçi Kitab-1 Mukaddes, bu iki yorum tarzı içinde değişik şekillerde anlaşılmıştır ve bu yüzden ona otorite sağlayan şeyin ne olduğu konusunda farklılıklar bulunmaktadır. Bu farklılıkları besleyen kategorik ayrımlar (söz gelimi dolaylılık ve doğrudanlık ayrımı 
gibi), meseleye ilgi duyan kimseler için yabancı değildir. ${ }^{4}$ Burhanettin Tatar'ın dikkat çektiği üzere belki de bu tür farklıkları besleyen en temel sorunlardan biri, 'kutsal metin' ve 'otorite' kavramlarının yan yana kullanılmasıyla oluşan 'kutsal metnin otoritesi' ifadesindeki anlam belirsizliğidir. Zira Tatar'a göre hem kutsal metnin hem de otoritenin asla boşlukta değil, aksine daima dönüşüm içinde bulunan tarihsel ortamlar içinde tezahür edebileceğini fark ettiğimizde, her şeyden önce kendimizi form ile muhteva arasındaki ayrışmanın ortasında buluruz. ${ }^{5} \mathrm{Bu}$ tarz kategorik ayrımlar, kutsal metnin otoritesi ve bu otoritenin kapsamı konusunda doğal olarak farklı görüşleri de beraberinde getirmiştir. Bu yüzden kimi araştırmacıların fark ettiği gibi Hıristiyan dünyada kutsal metin bağlamında 'otorite' kelimesinin anlamı farklı kiliselerde değişik şekillerde yorumlanabilmiştir. ${ }^{6}$ Söz gelimi Orta Çağ' da kutsal metnin otoritesi, Kilise otoritesinin bir parçası olarak kabul edilmekteydi. Buna karşın Reformasyon, bu otoriteyi kutsal metni daha da güçlendirmek maksadıyla bizzat metnin kendisinde topladı. Westminster İnanç Bildirgesi bunun tipik örneğidir. ${ }^{7}$ James Barr'ın dikkat çektiği üzere bu bildirge, Protestan kanonunun toplam altmışaltı kitabının tamamının vahiy ürünü olduğunu ve başka hiçbir kitaptan esinlenilmediğini

4 Kutsal metin ile okur arasında doğrudanlık ve dolayllık ilişkisi hakkında bk. Asim Duran, Aydınlanma ve Kutsal Kitap (Samsun: Üniversite Yayınları, 2017), 20-32. Reformasyon teolojisinde doğrudanlık ve bu bağlamda kutsal metnin otoritesi autopistia kavramı çerçevesinde ele alınmıştır. Kavramın Reformasyon teolojisindeki dönüşümü ve kutsal metnin otoritesiyle bağı için bk. Henk van den Belt, The Authority of Scripture in Reformed Theology: Truth and Trust (Leiden, Boston: Brill, 2008). Ayrica bk. Robert Kolp, "The Bible in the Reformation and Protestant Orthodoxy", The Enduring Authority of the Christian Scriptures, ed. D. A. Carson (Grand Rapids/Cambridge: Wm. B. Eerdmans Publishing Co., 2016), 99-103.

5 Burhanettin Tatar, "Kutsal Metin ve Otorite: Tarihsel-Fenomenolojik Bir Analiz", Milel ve Nihal 14/1 (2017): 65-66.

$6 \quad$ N. T. Wright bunun sebebini, kavramın içeriğinin farklı dönemlerdeki bağlamlara göre sürekli değişmesine bağlar. Bu yüzden o, tek bir noktadan hareketle otorite kavramını ele almanın sorunlarına işaret etmiştir. Bu kullanımların derli toplu kısa incelemesi için bk. N. T. Wright, "How Can the Bible Be Authoritative? (The Laing Lecture for 1989)", Vox Evangelica 21 (1991): 8-13. Ayrica bk. Tatar, "Kutsal Metin ve Otorite", 66-68; John W. Rogerson, "Historical Criticism and the Authority of the Bible", The Oxford Handbook of Biblical Studies, ed. J. W. Rogerson ve Juddith M. Lieu (Oxford: Oxford University Press, 2006), 849.

7 Söz konusu bildirinin birinci bölümünde, Kutsal Kanon'da bulunan metinlerin Tanrı tarafından ilham edildiği ve dolayısıyla otoriter olduğu vurgulanmıştır. Buna karşın apokrif metinler bu özel otoritenin dışında tutulmuştur. Bk. The Confession of Faith of the Assembly of Divines at Westminster, ed. S. W. Carruthers (London: Publishing Office of the Presbyterian Church of England, 1946), Bölüm 1. 
ifade etmektedir. Böylece tüm doktriner formülasyonlar, kesin olarak kutsal kitabın rehberliği ve kontrolü altında olacaktı; mukayese edilebilir başka bir otorite kaynağının değill. ${ }^{8}$

Bu tarz değişkenliklere rağmen yine de bu yazının ele almaya çalıştığı konu açısından bakıldığında her iki yorum tarzı arasında en azından kutsal kitabın Tanrı Kelamı olarak yanılmazlığı ve dolayısıyla otoriterliği konusunda bir mutabakatın olduğu söylenebilir. Buna göre, hem Orta Çă̆ Katolik Kilisesi'nin gözetimi altında hem de Reformasyon'un Protestan yorum tarzları içinde Kutsal metinde konuşan bizzat Tanrı'dır. Ayrıca metin, form ve muhteva açısından yanılmaz ve otoriter olarak kabul edilmiştir. ${ }^{9}$ O nedenle bahsi geçen dönemlerde kutsal metnin belli bir forma kavuşmasını sağlayan kanonlaşma süreci ile onun otoriterliği arasında doğrudan bir bağ bulunmaktadır. Bunun tipik örneği, kutsal kanon bağlamında Septuagint ve Vulgate yazmaları arasındaki biçimsel farklılıklara yönelik tartışmalardır. ${ }^{10}$ Dahası eldeki en eski yazmayı bulma teşebbüsünün bir parçası olarak Kilise tarafından organize edilen 'metin eleştirisi' (textual criticism) çalışmaları ve tartışmaları burada hatırlanabilir. Bu tartışmalar, genel olarak hangi metinlerin kutsal kanona dâhil edilip edilmeyeceği noktasında toplanmıştı. Protestan ortodoksisi, bu tartışmalarda kanonun içeriğini belli biçimsel formlarla ve metinlerle sınırlandırdı. Fakat yine Barr'ın dikkat çektiği üzere antik yazıların

8 James Barr, Holy Scripture: Canon, Authority, Criticism (Oxford: Clarendon Press, 1983), 23-25. Yine de Reformasyon teolojisi, İsa'nın bedeni olarak Kiliseyi bütünüyle reddetmemiştir. Fakat kutsal kitap yorum geleneğini reddetmeksizin nihai otoritenin, Kilise'ye değil de kutsal kitabın bizzat kendisine ait olduğunu göstermek maksadıyla bir ayrıma da dikkat çekilmiştir. Buna göre kutsal metnin otoritesinin anlaşılması, İsa'nın Kelamı ile İsa'nın bedeninin otoritesinin birbirinden farklı olduğu düşüncesine dayanmaktadır. Bk. Willem van Vlastuin, "Sola Scriptura: The Relevance of Luther's Use of Sola Scriptura in De Servo Arbitrio", Sola Scriptura: Biblical and Theological Perspectives on Scripture, Authority, and Hermeneutics, ed. Hans Burger vd. (Leiden, Boston: Brill, 2018), 246-247.

9 Katolik Kilisenin ikinci Vatikan Konsili'ne kadar kutsal metne yönelik yaklaşımının derli toplu açıklamaları ve bu bağlamda ortaya çıkan Kilise içi tartışmalar için bk. Fitzmyer, The Interpretation of Scripture, 1-36. Yine Protestanlık içinde kutsal metnin yanılmazlık (inerrancy) doktrini hakkında bk. Kenneth S. Kantzer, "Evangelicals and the Doctrine of Inerrancy", The Foundation of Biblical Authority, ed. James Montgomery Boice (London-Glasgow: Pickering \& Inglis, 1979), 147156.

10 Kutsal yazıların kanonlaşma sürecinin otorite kavramıyla bağı konusunda bk. Allan K. Jenkins \& Patrick Preston, Biblical Scholarship and the Church: A SixteenthCentury Crisis of Authority, ed. Allan K. Jenkins ve Patrick Preston (Hampshire: Ashgate, 2008), ix-x, 3-26. 
otoriter metinler olarak kutsal kanona dâhil edilip edilmemesi, bu yazılarla ilişkilendirilen şahıslarla her zaman doğrudan bağlantılı olmuştur. Buna göre söz gelimi, Romalılara Mektup bir kutsal metin olarak otoriteye sahiptir. Zira Pavlus'un kendisi otoriterdir. Daha genel ifadeyle söylenirse, İsa Mesih nedeniyle İnciller otoritedir. Bu nedenle bir inanç biçimi olarak Hıristiyanlık, ilk olarak bir kitaba değil o kitabın içindeki ve arkasındaki insanlara; bağlamları olan ve kendilerini tanıttıkları eski toplumun yaşamına yöneliktir. Bu yüzden, Aydınlanma ve sonrası dönemde, kutsal metne yönelik eleştirel çalışmalar, bu yaşamdan, yani tarihsel ortamdan ve bu kişilerden daha fazla şey bilme konusunda en azından Kilisenin temelini oluşturan otoritenin ne olduğunun anlaşılmasına, doğrudan katkı sunmayı hedeflemektedir. ${ }^{11}$ Barr'ın Aydınlanma dönemindeki eleştirel çalışmaların zeminine dair bu yaklaşımı, kutsal metinlerin form ve muhtevası ile bu metinlerin ardındaki tarihsel hadiseler arasında var olduğu düşünülen derin gerilime dikkat çekmesi yönüyle önem arz eder. Tam da bu noktada yukarıdaki satırlarda Tatar'ın kutsal metinlerin otoritesinin asla boşlukta değil, her zaman tarihsel ortamlar içinde sürekli dönüşüm geçirerek tezahür ettiğine dair ifadelerini yeniden hatırlamakta fayda var. Yine de bazılarımız tarafından Barr'ın yaklaşımı fazlasıyla iyimser olarak nitelendirilebilir. Çünkü Aydınlanma sonrası tarihsel-eleştirel çalışmalar, her ne kadar bu metinlerin ardındaki tarihsel ortam hakkında bize birtakım bilgiler sunsa da nihayetinde kutsal metnin (en azından geleneksel açıdan) otoritesinin sarsılmasının ve nihayet onun tahttan indirilmesiyle sonuçlanan sürecin yolunu da açmıştır.

Şu hâlde, topyekûn bir hareket olarak Aydınlanma döneminde akla ve bilime duyulan güvenin artması, dolayısıyla da dini olsun ya da olmasın her türlü otoritenin felsefi rasyonel muhakemelere tabi tutulmasıyla başlayıp ${ }^{12}$ sonra daha derin tarihsel araştırmalarla ilerleyen eleştirel çalışmaların, başlarda metin eleştirisinin bir devamı olarak edebi bir ilgiyle sürmesi şaşırtıcı değildir. Bununla birlikte ilk dönem eleştirel çalışmaların, kutsal kanon ve geleneğin (form ve muhteva) yeri konusunda Katolik Kilise ile Protestan ortodoksisi arasında süregelen klasik tartışmaları devam ettirdiği de tahmin edilebilir. Bunun tipik örneği, tarihsel eleştirinin ilk önemli

11 Barr, Holy Scripture, 47-48.

12 Sait Kar, "Din, Aydınlanma ve Eleştirisi", Atatürk Üniversitesi İlahiyat Fakültesi Dergisi 42 (2014): 174-175. 
isimlerinden biri kabul edilen Katolik ilim adamı Richard Simon'dur (1638-1712). Simon'un kutsal kitap eleştirisi, kanon ve gelenek tartışmalarının bir parçası olarak büyük oranda Protestan yorum tarzının (yani Luther'in) ve aynı zamanda salt metin merkezli rasyonel eleştirinin (yani Spinoza'nın) zemininin yanlışlı̆̆ını ortaya koymak gibi bir amaca yaslanıyordu. Simon, geleneğin uzun asırlar boyunca kutsal metinleri derlediğini ve revize ettiğini tarihsel-filolojik araştırmalar yoluyla göstererek bir bakıma Katolik Kilise'nin geleneksel kutsal kitap anlayışını (otorite) desteklemeye çalışmıştır. ${ }^{13}$ Böyle bir geleneksel arka plana yaslansa da günümüzde onun çalışmaları, modern kutsal kitap eleştirisinin ve tarihsel eleştirinin başlangıçlarından biri kabul edilir.

Öyle anlaşıliyor ki hem liberal eleştirmenler hem de muhafazakâr ilahiyatçılar, yeni bir yorum tarzı olarak tarihsel-eleştirel çalışmalar vasıtasıyla kutsal metnin ardındaki tarihin, sosyo-kültürelpolitik bağlamın gerçek bilgisini elde edebilecekleri idealiyle motive edilmişlerdi. Onu bütünüyle reddetmek ve dini-sosyal yaşamdan uzaklaştırmak gibi radikal bir kararla değil. Bunda elbette, Reformasyon'un Orta Çağ boyunca devam eden yorum tarzını değiştirmesinin etkisi büyüktür. Hatırlanacağı üzere Orta Çağ Katolik Kilisesinde büyük oranda metnin manevi anlamını (the spiritual sense) ön plana çıkaran bir yorum tarzı vardı. Tipolojik veya Alegorik yorum bunun bir parçası olarak işlev görüyordu. Reformasyon, bunun karşısında metnin literal yani doğal anlamını ön plana çıkardı. Aydınlanmanın eleştirmenleri büyük oranda Reformasyon'un bu tekli yorum tarzını (literal sense) miras aldılar ve kendi eleştirel yorumları için bir kalkış noktası olarak kullandılar. Tarihsel eleştiriyle birlikte bu manevi anlam büyük oranda dikkate alınmadı. ${ }^{14} \mathrm{Bu}$ durum, metnin literal olarak anlaşılmasında kutsal metin dışı kriterlerin ortaya çıkmasını zorunlu kılmıştır. Böylece kutsal metin dışı kaynaklar, metnin arka planının anlaşılmasının ve dolayısıyla kutsal metnin yorum sürecinin bir parçası haline geldi. Bilhassa eleştirel bilim ta-

13 Simon, bunu ilgili kitabın Mukaddime'sinde özellikle vurgular. Hem Luther'in hem de Spinoza'nın yaklaşımlarının yanlışlığını Katolik bakış açısından tartışır. Richard Simon, A Critical History of the Old Testament (London: Walter Davis, 1682).

14 Brevard S. Childs, "The Sensus Literalis of Scripture: An Ancient and Modern Problem", Bieträge zur Alttestamentlichen Theologie, ed. Herbert Donner vd. (Göttingen: Vandenhoeck \& Ruprecht, 1977), 80-93. 
raftarları, metnin muhtevası ile onun derlenmesini birbirini tamamlayan süreçler olarak gördükleri için kutsal metinleri, asli durumlarındaki işlevselliklerine geri götürebileceklerine inandıkları bir tür kuşkuculukla ele aldılar ve kutsal kitap dışı kaynaklar veya [eleştirmenlerin diliyle söylersek 'diş kanıtlar' (external evindence)] yoluyla metnin sosyo-kültürel-tarihsel bağlamının daha ayrıntılı araştırmalarına giriştiler. Bunu yaparken onlar, (Tatar'ın ifadesiyle) "kutsal metinlerin ön planındaki anlam dünyasını, bu metinlerin arkalarındaki anlam dünyasına, yani metinlerin içinde ortaya çıktığ 1 tarihsel bağlamlara indirgenebileceği" çabasından hareket ettiler. ${ }^{15}$ Bu yüzden kutsal metnin kaynağına dair söz gelimi çoğunlukla J. Wellhausen' in (1844-1918) ismiyle anilan belge hipotezi (documentary hypothesis) gibi on dokuzuncu yüzyılın kayda değer hipotezleri, geleneksel metin eleştirisinin bazı buluşları ile on yedi ve on sekizinci yüzyılın rasyonel muhakemeleri yoluyla ulaşılan bazı gelişmelerin üzerine kurulmuştur. Bilhassa on sekizinci yüzyıldan itibaren ve daha radikal bir şekilde artarak on dokuzuncu yüzyılda bu eğilimler ve gelişmeler, kutsal metnin otantikliği sorununu gündeme getirerek onun otoritesini ve böylece geleneksel Hıristiyan inancını tehdit edecek tarzda sentezlendi ve uyguland1.

Kitab-1 Mukaddes eleştirisi tarihine yönelik kimi çalışmalar, bu süreci birkaç başlık altında toparlamışlardır. İlki, kanonik metinler olarak kutsal kitabın otantikliği sorunu. Burada eleştirel tefsirler, antik döneme ait farklı yazılar gibi bazı paralel metinler yoluyla metnin tarihi (history of the text) bağlamında kutsal kitap tartışmaya açıldı. İkincisi, metindeki tarih (history in the text) bağlamında önce İsrail tarihinin, sonrasında ise İsa'nın tarihsel yaşamı (historical Jesus) hakkında biblikal açıklamaların araştırılması. Üçüncüsü ise kutsal metindeki doğaüstü olduğu düşünülen anlatılardan yola çıkarak geleneksel inancın sorgulanması. ${ }^{16}$ Çoğunlukla birbirine paralel

15 Tatar, bu durumu 'metne karşı şiddet politikası' olarak nitelendirir. Ona göre "tarihsel eleştiri, indirgeyici çabası içinde metinlerin farklı tarihsel bağlamlara yönelen ön plandaki dinamik anlam dünyasına şiddet uygular, onların yorumcularla olan tarihsel etkileşim içindeki açılımlarını yani tarihsel hayatını göz ardı ederek metinleri asla tekrarlanamayacak orijinal bağlamlarına geri dönmeye zorlar." Burhanettin Tatar, "Kur'ân'1 Yorumlama Sorunu", Kur'an ve Dil: Dilbilim ve Hermenötik Sempozyumu Bildirileri (Van, 17-18 May1s 2001), ed. Necati Kara, (Erzurum: Bakanlar Matbaasi, 2001), 504-505.

16 John H. Hayes \& Carl R. Holladay, Biblical Exegesis: A Beginner's Handbook, Gözden geçirilmiş baskı (Atlanta: John Knox Press, 1973), 45-52; John Barton, The 
ilerleyen bu süreçler, bazı istisnalar dışında ilk başlarda kutsal kitabı ve ondaki anlatıları reddetmek gibi radikal bir amaçla gerçekleşmemiştir. Aydınlanmanın birçok eleştirmeni için metinlerdeki bu ifadeleri kabul etmek zor olsa da onlar, daha çok bu metinleri kompoze eden ve derleyen kimselerin niyetlerine ve yorumlama tarzlarına odaklanan bir tür niyetselci-tarihsel araştırmayı kullandılar. Metinlerdeki doğaüstü ve mucizevi göndermeler içeren pasajların daha makul doğal açıklamalarını arayan bir kutsal kitap yorumu geliştirmeyi hedeflediler. Rogerson'a bakılırsa bu kimseler, belki de ilk "mitolojiden arındırmacılar" (demythologizers) olarak Kitab-1 Mukaddes'in değerini tarihsel bir kaynak olarak kabul eden bir yorum yöntemini savunmuşlardır. ${ }^{17}$ Bilhassa İngiltere'de deistler, Alman üniversitelerinde bazı muhafazakâr ilahiyatçılar, Amerika'da Evanjelik Protestanlar, en az liberal eleştirmenler kadar belli bakımlardan kutsal metnin rasyonel bir yorumunu geliştirmeye ilgili olmuşlardır. ${ }^{18}$ Esasında farklı çevrelerce öne çıarılan bu tarz rasyonel yorumlar, kutsal metnin yanılmazlığını (inerrancy) doğrulamak gibi belli ölçüde geleneksel bir amaca da yaslanıyordu. Fakat kabul etmek gerekir ki yanılmazlık doktrinine yönelik vurgu tarihsel eleştiriye karşı bir tepkiyi de içermektedir. Yine de kabaca on yedinci yüzyıldan başlayarak yirminci yüzyılın başlarına kadar yükselerek devam eden tarihsel-eleştirel çalışmalar hem Avrupa'da hem de Amerika'da kutsal kitaba sadakati azalttı ve farklı çevrelerde geleneksel inancın sorgulanmasına yol açtı. Bu yüzden, geleneksel yorum tarzlarını ters yüz eden ve çoğunlukla üniversite kürsülerinde kurgulanan bu tarz çalışmaların, Kilise tarafından şüpheyle karşılanması şaşırtıcı değildir.

Burada tüm bu sürecin kutsal metinlerin, kutsal olmayan antik metinlerden ve seküler prensiplerden hareketle yorumlanması gibi önemli bir sorunu yarattı̆̆ görülebilir. Bu yüzden modern tarihsel-

Nature of Biblical Criticism (Louisville and London: Westminster John Knox Press, 2007), 39-44.

17 Rogerson, "Historical Criticism and the Authority of the Bible", 849-850.

18 Michael J. Lee, liberal eleştirmenler karşısında muhafazakârların kutsal metni savunmak maksadıyla rasyonel bir yorumla nasıl uyum sağladıklarını göstermeye çalışmıştır. Bu yüzden o, modern dönemde kutsal metnin tahttan indirilmesiyle sonuçlanan süreçten en az liberal eleştirmenler kadar muhafazakârları da sorumlu tutar. Bk. Michael J. Lee, The Erosion of Biblical Certainty: Battles over Authority and Interpretation in America (New York: Palgrave Macmillan, 2013). 
eleştirel çalışmaların yükselişi, sadece Kitab-1 Mukaddes'i yorumlama yöntemleri konusunda değil, teolojik düşüncenin tüm alanlarında köklü değişikliklere yol açmıştır. Richardson'a göre hiçbir teolojik disiplin, on sekizinci yüzyılın sonlarına kadar sahip olduğu karakter ve yöntemle kalmadı. ${ }^{19}$ Tarihsel-eleştirel çalışmalar, bir taraftan kendi içinde değişimler yaşarken diğer taraftan farklı kesimlerden gelen değişik reaksiyonlar nedeniyle geleneksel teolojileri de dönüştürerek onların modern kültürle uyum sorununu gündeme getirdi. Bu çerçevede geleneksel dogmatik ve sistematik teoloji (systematic theology) karşısında bilhassa 'bilimsel teoloji' ve 'tarihsel teoloji', kutsal kitap teolojisinde (biblical theology) popüler yönelimler haline geldi. ${ }^{20}$ Dahası kutsal metnin eleştirel yorumuyla ilgilenen ilim adamları da söz konusu dönüşümlerden etkilendiler ve hatta bunun bir parçası olarak sürece katkı sağladılar. Fakat hem kutsal metnin otoritesinin sarsılması hem de teolojik düşüncede yaşanan köklü değişikler, (bazı istisnalar hariç tutulacak olursa) kutsal kitabı tamamen ortadan kaldırmak gibi radikal bir kararla yapılmamıştır. Daha ziyade bu metinlerin ardındaki otoriter şahısların ve onlarla ilişkili hadiselerin daha derin tarihsel bilgilerini elde etmek ve böylece kutsal metnin daha rasyonel ve tarihsel yorumunu geliştirmek maksadıyla yapılmıştır. Bu anlamda dönemin eleştirel çalışmalarına belli ölçülerde dindar bir okuma eşlik eder ve çoğunlukla bu ikisi arasındaki gerilim, kabaca on yedinci yüzyıldan itibaren hemen hemen tüm çalışmalarda kendini bir şekilde gösterir.

Henry Nash, Yeni Ahit eleştirisi tarihi üzerine yazdığı eserinde bu gerilimi, bilme arzusu ve kurtarılma arzusu gibi iki beşerî duygu ile açılar. Ona göre her ikisi de dindarlığın bir parçası olarak kutsal metnin derin bilgisini elde etmek amacıyla işlev görmektedir. Yine de kutsal metnin dindar bir okuması çoğunlukla bilimsel ilgiler tarafından rahatsız edilmiştir. ${ }^{21}$ Kutsal kitap eleştirisi tarihine yönelik

19 Richardson, "The Rise of Modern Biblical Scholarship", 304-305.

20 Jaroslav Pelikan, Historical Theology: Continuity and Change in Christian Doctrine (Eugene, Oregon: Wipf\&Stock, 2014), xiii-xxi. Ayrıca 'tarihsel teoloji'nin amacı ve Hıristiyanlık tarihi açısından önemi hakkında bk. Alister E. McGrath, Historical Theology: An Introduction to the History of Christian Thought, ikinci basim (Malden, MA: Wiley-Blackwell, 2013), 8-15.

21 Nash, bunun için on dokuzuncu yüzyılın en önemli tarihçilerinden Leopold von Ranke'yi model olarak gösterir. Gerçi Nash, sağlam bir kutsal metin yorumunun bu iki duygunun birleşimiyle ortaya çıabileceğini savunmaktadır. Bk. Henry S. Nash, The History of the Higher Criticism of the New Testament (New York: The Macmillan Company, 1900), 5-8. 
benzer bir okuma Morgan ve Barton'da da görülür. Her ikisi, Biblical Interpretation (Kutsal Kitap Yorumu) isimli çalışmalarında geleneksel dindarlık ile bilimsel ilgiler ve rasyonel muhakemeler arasındaki gerilime dikkat çektiler. Onlara göre Kitab-1 Mukaddes'in anlatılarıyla ilgilenen bazı tarihçiler az ya da çok dini ilgilere sahiptiler. Birçok biblikal ilim adamı ise aynı zamanda inanan ve dindar insanlardır. Bu ikincilerin bir kısmı dini inançlarını kendi eleştirel akıllarıyla bütünleştirmeye çalışmışlardır. ${ }^{22}$

Öyle anlaşılıyor ki Aydınlanma sonrasında kutsal metnin yorumuyla ilgilenen eleştirmenler ve ilahiyatçılar, büyük oranda bu iki duygu arasında kendilerini sıkışmış hissettiler. Çünkü ilki, kutsal metnin açıklamalarının güvenilirliği konusunda İngiliz deizmi ile Kıta Avrupası kuşkuculuğunun tesiri altında, geçmişteki biblikal olayların tarihsel olarak gerçekte ne şekilde olduğuna (what really happened) dair bir merakı tetiklemiştir. Bilhassa on dokuzuncu yüzyıl romantizmi ve idealist tarihselciliği içinde yetişen ve bu bağlamda insanlık tarihine ilgi duyan hiçbir eleştirmen buna kayıtsız kalamamıştır. ${ }^{23}$ İkincisi ise bizzat kutsal kitap ve Kilise tarafından gelenek yoluyla oluşturulmuş geleceğe yönelik bir kurtuluş (salvation) beklentisi tarafından motive edilmiştir. Bu yüzden dönemin birçok eleştirmeninin ve ilahiyatçısının çalışmalarında bu ikisi arasındaki gerilimin izleri görülebilir. Bahsi geçen gerilimde bazı liberal eleştirmenler, kutsal kitabın yanılmazlığını ve dolayısıyla her alandaki otoritesini kabul etmeyen daha seküler bir çizgiyi takip ettiler. Metnin otoritesini dini alanla sınırlandırdılar. Çoğunlukla onların yaklaşımları, kutsal kitabın herhangi antik edebi metin (literary text) olarak görülmesine kadar vardı. Bu bağlamda onlar, otoriter bir metin olarak kutsal kitaba yeni bilim karşısında fazla şans tanımadılar. Birçok eleştirmen, edebi metinler için uygulanan prosedürlerin kutsal metin için de uygulanabileceğini varsaymıştır. Louis Cappel (1585-1658) ve Benjamin Jowett'in (1817-1893) bu konudaki görüşleri on yedinci yüzyıldan on dokuzuncu kadar bu husustaki

22 Robert Morgan \& John Barton, Biblical Interpretation (Oxford: Oxford University Press, 1988), 16-17.

23 Gunter Scholtz, "The Phenomenon of 'Historicism' as a Backcloth of Biblical Scholarship", Hebrew Bible/Old Testament: The History of Its Interpretation III/1: Nineteenth Century, ed. Magne Sæbø (Göttingen: Vandenhoeck \&Ruprecht, 2013), III/1:75. 
istikrarı özetlemektedir. ${ }^{24} \mathrm{O}$ nedenle topyekûn bir hareket olarak tarihsel-eleştirel çalışmaların en azından kutsal metin yorumuyla ilgilenen kimseler için yarattığı sorun, sadece entelektüel çaba ve tarihsel araştırma sorunu olarak kalmamıştır.

Kuşkusuz Aydınlanma döneminin eleştirmenleri, kutsal metne karşı bu tarz eleştirel yönelimin dindar bir okumayı tehlikeye atacağının farkındaydılar. Çünkü kutsal metnin eleştirel bir gözle araştırmanın önemine içtenlikle inanan ilk eleştirmenler, çoğu zaman dönemin otoriter dini makamlarıyla acı çatışmalara da girişmişlerdir. B. Spinoza ve R. Simon, bunun sembol isimlerinden ikisi olarak burada hatırlanabilir. O dönemlerden bu yana tarihsel eleştirinin gelişimini takip eden bir araştırmacı, bu iki yönlü baskı akışını izleyebilir. Yine de kabaca on yedinci yüzyıldan başlayarak devam eden yüzyıllarda ve hatta on dokuzuncu yüzyılda bile birçok eleştirmen, kutsal metnin otoritesini bütünüyle reddeden bir yorum geliştirmekte istekli değildir. ${ }^{25} \mathrm{Bu}$ yüzden onlar, geleneksel inanç biçimleriyle olan bağlarını tamamen ve hızlı bir şekilde koparmadılar. Daha ziyade, modern tarihsel-eleştirel çalışmaların verileriyle kutsal metnin otoritesini bir arada yürütebilecek bir teoloji ve kutsal kitap anlayışı geliştirmeye meyilli olmuşladır. Bunu da eleştirinin daha da ileri götürülmesini sağlayacak modern dindarlıklarıyla uyumlu bir şekilde yapmaya çalışmışlardır. Böylece şekillenen Aydınlanmacı teoloji, kilisenin otoritesini sarsmakla birlikte, kutsal kitabın dolayısıyla da Hristiyanlığın Batı düşüncesi üzerindeki etkisini ortadan kaldırmamış ve her şeye rağmen Hristiyanlık, Avrupa kimliğinin kurucu unsurlarından biri olmayı sürdürmüştür. ${ }^{26}$

24 Benjamin Jowett, "On the Interpretation of Scripture", Essays and Reviews, ed. Frederick Temple ve diğerleri (London: John W. Parker and Son, 1860), 338, 404; Benedetto Bravo, "Critice in the Sixteenth and Seventeenth Centuries and the Rise of the Notion of Historical Criticism", History of Scholarship, ed. Christopher Ligota, Jean-Louis Quantin (Oxford: Oxford University Press, 2006), 183.

25 Mark Noll, öte yandan bazı dindar eleştirmenlerin, kutsal metne dair daha derin bir eleştirel araştırmanın geleneksel inançları yeniden revize etmeyi gerektirebileceğini düşündüklerini söyler. Ona göre bu kimseler, farklı yapılarda ve gruplarda olsalar da nihayetinde kutsal metnin temel yapısına, realistik yorumuna ve nihai otorite olduğuna inanç gibi önemli konularda, kendilerini muhafazakâr tutum takınan evanjeliklerle bir tutmuşlardır. Noll, Between Faith and Criticism, 156-160. Ayrıca bk. Hays, "Towards a Faithful Criticism", 3, 7.

26 Sait Kar, "Felsefi Açıdan İslamofobi ve Eleştirisi", İlahiyat Tetkikleri Dergisi (ILTED) 47 (2017): 204. 
Buraya kadar çerçevesini çizmeye çalıştığımız tabloyu dönemin önemli bazı eleştirmenleri üzerinden örneklendirebilir miyiz? Daha açık ifadeyle, on yedinci ve on sekizinci yüzyılda kutsal kitap eleştirmenleri ve ilahiyatçıları, tarihsel eleştiri ile kutsal metnin otoritesi arasındaki gerilimi nasıl aşmaya çalıştılar? Bu bağlamda onlar ne tür bir kutsal kitap ve vahiy teolojisi geliştirdiler? Bu tarz uyum ve arabuluculuk teolojileri, modern eleştirel çalışmalar açısından ne anlama gelmektedir?

\section{Eleştirmenler Otorite Sorununu Nasıl Aşmaya Çalıştılar?}

Görebildiğimiz kadarıla eleştirmenler ve ilahiyatçılar, bu sorunu birbiriyle bağlantılı dört ana hususu eş zamanlı bir süreç içinde kombine ederek aşmaya çalışmışlardır. Öncelikle onlar, büyük oranda Reformasyon'dan miras aldıkları ve Kilise'den bağımsız kutsal kitap merkezli dindarlık anlayışını Aydınlanmanın rasyonel mekân anlayışı içinde yeni ve modern bir dindarlık türüyle birleştirdiler. ${ }^{27}$ İkinci olarak kutsal metin ve vahiy anlayışlarını bu yeni dindarlıklarıyla uyumlu bir şekilde yeniden kurguladılar ve bu konuda Kilise babalarından ayrıldılar. Üçüncü olarak onlar, eleştiri kavramını yeniden revize ederek doğa bilimleri ve antik metinler için daha öncesinden uygulanan eleştirel prosedürleri, kutsal kitap için de uygulanabilir hale getirdiler. Nihayet, Kitab-1 Mukaddes'in diğer antik metinlerle ilişkisini ortaya koymak ve ondan neşet eden dini geleneği, diğer dinlerle karşılaştırmanın bir yolunu açmak için kutsal metnin kanonik statüsünü ve geleneksel otoritesini bir kenara koydular; onun otoritesini eleştirel çalışmalarla uyumlu olacak şekilde dönüştürdüler ve onu tarihsel araştırmaya açık hale getirdiler. Tarihsel araştırma, söz konusu metinlerin ortaya çıtıkları tarihsel bağlam ve ortamların bilgisini elde etmenin en uygun yolu olarak dönemin birçok tarihçisi ve ilahiyatçısı tarafından önemsenmiştir. ${ }^{28}$ Böylece hem modern tarihsel-eleştirel çalışmaların verilerine kayıtsız kalmadılar ve kutsal metin dışı kaynakları kutsal metinlerin araştırmasında ana kriter haline getirdiler hem de (bazı istisnalar

27 Buradaki rasyonel mekân kavramının içeriği hakkında bk. Duran, Aydınlanma ve Kutsal Kitap, 50-67.

28 On altı ve on yedinci yüzyılda 'eleştiri' kavramının dönüşümü, bu çerçevede tarihsel eleştiri kavramının yükselişi ve bunların kutsal metnin eleştirel incelemesiyle ilişkisi konusunda B. Bravo'nun araştırması ilginç bilgiler sunuyor. Bk. Bravo, "Critice in the Sixteenth and Seventeenth Centuries", 135-195. 
dikkate alınmazsa) kutsal metni bütünüyle reddetmek ve Hıristiyanlığın dişına çıkmak gibi radikal bir dönüşüm geçirmediler. $\mathrm{Bu}$ yüzden söz konusu sürecin, dönemin araştırmacılarını büyük oranda 'vahiy' ve 'Tanrı Kelamı' kavramları üzerinde yoğun bir tartışmaya sevk etmesi anlaş1lır bir durumdur. Kutsal metnin otantikliği, yanılmazlığı ve dolayısıyla otoritesine dair bu tarz tartışmalar, tarihsel eleştirinin öncüleri olarak kabul edilen isimlerin çalışmalarında görülebilir.

Söz gelimi, bunun ilk tipik örneklerinden biri, Protestan kökenli Arminyanizm taraftarı Hugo Grotius'un (1583-1645) Hiristiyan Dininin Hakikati (1627) isimli apolojetik çalışmasıdır. Aslen hukukçu olan Grotius, bu eserinde Yeni Ahit metinlerinin ve dolayısıyla Hiristiyanlığın kendi antik ortamlarında anlaşılması gerektiğini savunmuştur. Bu yüzden söz konusu metinlerin otantikliği sorunu onun temel ilgi alanlarından biriydi. Bunu ise çoğunlukla, Kilise merkezli 'metin eleştirisi' (textual criticism) yoluyla yapmıştır. Ona göre, uzun bir metin geleneğinde el yazmaları kopyalanırken bazı hataların olması gayet normaldir. Fakat o, bu el yazmalarının kasıtlı olarak değiştirildiği iddiasını reddeder. Dahası, vahiy ve ilham kavramlarının çerçevesini genişleterek ve bu metinlerin yazarlarına kutsallık atfetmek suretiyle biblikal metinlerin güvenilirliğini savunmaya çalışmıştır. Aynı şekilde Eski Ahit metinlerinin otoritesi de Yeni Ahit metinlerinin anlaşılmasında bağlamsal etkiye sahip olması dolayısıyla ele almak suretiyle geleneksel 'tipolojik yorum'u (typological interpretation) belli ölçüde devam ettirmiştir. ${ }^{29} \mathrm{Bu}$ perspektiften hareketle sonradan Yeni Ahit üzerine Notlar (1644) isimli eserinde bu tarz bir metin eleştirisi ve filolojik yorumu Eski Ahit metinlerine uygulamıştır.

Kümmel'e bakılırsa Grotius, bu şekilde metinlerin bağlamlarına özellikle dikkat çekmekle kendisinden sonraki birçok modern eleştirmen için bir kapı açmış oldu. ${ }^{30} \mathrm{Bu}$ yönüne rağmen onun kutsal metni araştırma tarzı, on dokuzuncu yüzyılın liberal eleştirmen-

29 Hugo Grotius, The Truth of the Christian Religion: In six Books, Corrected and Illustrated with Notes by Mr. Le Clerc, İngilizce'ye çev.: John Clarke, eklemelerle on beşinci baskı (Oxford: Printed by W. Baxter, 1818), 142-178.

30 Werner Georg Kümmel, The New Testament: The History of the Investigation of Its Problems, İngilizceye çev.: S. McLean Gilmour \& Howard C. Kee (Nashville: Abingdon Press, 1972), 33. 
leriyle kıyaslandığında dindar, savunmacı ve hata belli ölçüde politik bir arka plana yaslanır. O, hiçbir zaman Hiristiyan kutsal metinlerin otoritesini bütünüyle reddetmemiştir. Hatta tüm eleştirel çalışmalarını, Hıristiyanlığın nihai olarak en mükemmel din olduğunu kanitlama üzerine kurdu. ${ }^{31}$ Onun bu yaklaşımı, yani tüm eleştirel çalışmalara rağmen Hıristiyanlığın nihai olarak en mükemmel din olduğu ve Tanrı'nın kendini tarihin belli bir döneminde bu kutsal metinler üzerinde ifşa ettiğine dair düşünce, on yedinci yüzyllın sonlarında Richard Simon'dan başlayarak, on sekizinci yüzyıl boyunca İngiliz deistlerinin görüşlerinde ve on dokuzuncu yüzyılda Schleiermacher, Herder ve hatta Hegel'e kadar çeşitli dönüşümler geçirerek ve belki daha seküler bir çizgiye doğru evrilerek devam eder.

Aynı dönemlerde yaşayan Kalvinist Louis Cappel'i (1585-1658) de burada hatırlayabiliriz. Hakkında yapılan araştırmalardan hareketle, Grotius'la kıyaslandığında onun eleştirel çalışmalarında daha az savunmacı olduğu söylenebilir. Saumur'da Protestan Enstitüsü'nde İbranice hocası olan Cappel, Rönesans'tan beri antik metinler için uygulanan filolojik eleştirel prosedürleri kutsal metne uygulayan biri olarak öne çıkar. O da tıpkı Grotius gibi geleneksel metin eleştirisinden hareketle metnin literal anlamını öne çıkarmaya çalışan bir yöntemi takip ediyordu. ${ }^{32}$ Tüm araştırmasını, Eski Ahit metinlerinin antik metinler, erken dönem tercümeler, Talmud yazıları ve Masoretik metinlerle kıyaslanması ve karşılaştırması üzerine kurdu. Böylece İbranice metinlerdeki hareke ve ses işaretlerindeki bazı hataları tespit ederek bu metinlerin çeşitli dönemlerde değişime uğradığını ve redakte edildiğini gösterdi. Bu yüzden Cappel'in de her zaman temel ilgisi, bu metinlerin otantikliği sorunu üzerine olmuştur. Gray'a bakılırsa Cappel'in eleştirel çalışmaları, elbette kutsal metnin sözel olarak bütünüyle vahyedildiği şeklindeki geleneksel Protestan görüşe yönelik bir eleştiriyi de ima ediyordu. ${ }^{33} \mathrm{Bu}$

31 Grotius, The Truth of the Christian Religion, 85-135. Bu yüzden Nicholas Hardy, biblikal eleştiri tarihçilerinin Grotius'u katıksız bir eleştirmen olarak göstermelerini abartılı bulur. bk. Nicholas Hardy, Criticism and Confession: The Bible in the Seventeeth Century Republic of Letters (Oxford: Oxford University Press, 2017), 241243.

32 Bravo, "Critice in the Sixteenth and Seventeenth Centuries", 183.

33 Edward McQueen Gray, Old Testament Criticism: Its Rise and Progress, From Second Century to the End of the Eighteenth, A Historical Sketch (New York and London Harper \& Brothers Publishers, 1923), 69-72. 
yüzden, eleştirel sonuçlarla geleneksel inancın korunması arasındaki gerilim, Cappel'de bilhassa hissedilir. Onun, zamanla metinlerdeki bu tarz sorunların çözümünde daha dindar açılamalara yönelmesinde ona karşı güçlü bir muhalefetin etkisi büyüktür. ${ }^{34}$ Zira o, dönemindeki ve sonrasındaki birçok eleştirmen gibi tüm bu eleştirel sonuçlara rağmen, hiçbir zaman kutsal metinlerin otoriter olmadığı gibi radikal bir sonuca varmamıştır. ${ }^{35}$ Daha ziyade, kutsal metnin otoritesini kendi döneminde ulaşılan eleştirel sonuçlarla ve rasyonel muhakemelerle uyumlu bir biçimde yeniden tesis eden bir teoloji geliştirmeye istekli olmuştur. Legaspi'ye bakılırsa Cappel'in (ve John Morin gibi çağdaşlarının) çabası, kutsal metnin yorumunu düzenlemek ve metni muhafazakâr suiistimalden korumak için eleştirel bilimi kullanmaktı. ${ }^{36}$ Belli ki o (ve elbette çağdaşları), geleneksel ve muhafazakâr bir dindarlık dışında yeni bir dindarlık arayışı içindeydiler. Bu tarz bir teolojiyle, eleştiriye tabi tuttukları metnin modern kültürle uyumlu bir biçimde otoritesini hala korumasinın bir yolunu bulmuş olacaklardı. Bu yüzden onun, metin eleştirisi ve karşılaştırmalı filolojiye dayanan eleştirel muhakemesi ister istemez teolojik bir yorumla neticelenir. ${ }^{37}$

Fakat geleneğin önemini ve gücünü gösterme konusunda Richard Simon, kutsal kitap eleştirisi tarihinde belli ölçüde çağdaşlarından ayrılır. Spinoza ile birlikte modern kutsal kitap eleştirisinin en önemli öncülerinden kabul edilen Simon, belki de modern tarihsel-eleştirel çalışmaların sonuçları ile kutsal metnin otoritesinin (ve dolayısıyla imanın) korunması arasındaki gerilimi en derinden hisseden kimselerden biriydi. Aslen Katolik olan Simon, yukarıda da kabaca değinildiği üzere tüm eleştirel çalışmalarını Spinoza ve Luther karşıtlığ üzerine kurdu. ${ }^{38}$ Eski Ahit'in Eleştirel Tarihi (1678) isimli

34 Yaşadığı dönemde Cappel'e yapışan muhalefet ve eleştirilerin içeriği için bk. Johann Anselm Steiger, "The Develepment of the Reformatin Legacy", Hebrew Bible Old Testament: The Histoy of Its Interperetaion, II, ed. Magne Sæbø (Göttingen: Vandenhoeck \& Ruprecht, 2008), II:748-749.

36 Michael C. Legaspi, The Death of Scripture and the Rise of Biblical Studies (Oxford: Oxford University Press, 2010), 21.

37 Hardy, Criticism and Confession, 308-313. Hardy'ye göre, Cappel vakası, yalnızca 1650 yılında "kutsal eleştiri" (sacred criticism) alanında ortaya çıkan fay hatlarının özellikle açık bir örneğini temsil etmektedir (s. 371).

38 Simon, "The Author's Preface Translated out of French", A Critical History of the Old Testament (London: Walter Davis, 1682), sy. Güçlü Protestan karşıtllğ̆ına 
eserinde, eleştirel çalışmalarla metinlerin tarihsel sürecine dikkat çekerek vardığı sonuçlar, on dokuzuncu yüzyılın pozitivist ve liberal eleştirmenlerinin yolunu açsa da nihayetinde o, vardığ tüm radikal sonuçları geleneğin (Katolik Kilise) önemini göstermek gibi teolojik bir amaç için kullandı. O da tıpkı öncülleri İbn Ezra, Spinoza, Hobbes gibi biblikal metinlerin otantik olmadığını ve redaktörler tarafından bazı değişiklilere uğratıldığını kabul etmiştir. ${ }^{39}$ Dahası ona göre bir kimse, kutsal metinlerin bu şekilde farklı zamanlarda ve mekânlarda biçimlendiği bilgisine sahip olmadan bu metinleri mükemmel bir biçimde anlayamaz. ${ }^{40} \mathrm{Bu}$ yüzden metinlerdeki değişimi reddetmedi. Fakat bu süreçte biblikal yazarların niyetlerindeki samimiyeti öne çıaran dindar bir okuma modeli önerdi. Onun bu niyetselci-tarihsel yaklaşımı, vahiy kavramındaki esnek görüşüyle paralel ilerler. Zira Douglas A. Knight'in fark ettiği üzere o, metinleri kaleme alan kâtiplerin ve redaktörlerin ilham yoluyla bunu yaptıklarını söyleyerek, kutsal metne dair vahiy anlayışını oldukça genişletmiştir ve toplu ilham fikriyle metnin derlenme süreçlerine kutsallık atfetmiştir. ${ }^{41}$ Onun bu yönteminin, eleştirel çalışmalar ile iman arasındaki gerilimi aşma konusunda belli ölçüde yardımcı olduğu söylenebilir.

Yine de bu hususta belki de en somut adım, Alman Johann Salomo Semler (1725-1791) ve Johann David Michaelis'ten (1717-1791) gelmiştir. Kümmel'e bakılırsa her ikisi de esasında devrimci olmaktan ziyade, rasyonel düşünceyi muhafazakâr bir tutum içinde kombine eden bir yorum geliştirmişlerdi. Bu bakımdan geleneksel metin eleştirisine bağlı kaldılar. Fakat İngiliz deistlerin hem kutsal metin

rağmen yine de Simon'un bu çalışması, Katolik Kilise'nin 1678 yılındaki Yasaklanan Kitaplar Listesi'ne (Index Librorum Prohibitorum) girmekten kurtulamamıştır.

39 Simon, A Critical History of the Old Testament, 24-46, (I.III-V). Hobbes, Spinoza, Simon'un kutsal kitap eleştisine katkılarına dair daha geniş açıklamalar için bk. Duran, Aydınlanma ve Kutsal Kitap, 67-103.

40 Simon, "The Author's Preface Translated out of French", sy.

41 Douglas A. Knight, Rediscovering the Traditions of Israel, Third ed. (Atlanta: Society of Biblical Literature, 2006), 40. 
hem de vahiy konusundaki meseleleri rasyonel zeminde izah tarzlarından etkilendiler. ${ }^{42}$ Öte yandan Simon'un tarihsel-eleştirel araştırma tutumunu tüm bu sürece dâhil ettiler. Bu yüzden söz gelimi Semler'in kendisine kadar gelen eleştirel buluşları büyük bir heyecanla karşılamasında şaşılacak bir durum yoktur. Fakat o, tüm bu özgür araştırmalarında temelde iki tezi öne çıkarmıştı. İlki, kutsal kitap ile Tanrı Kelamı aynı şey değildir. Bu tezin onu ulaştırdığı ana sonuç, kutsal metnin bütünüyle Tanrı kelamı olmaktan ziyade onu 'kapsadığg' fikriydi. İkincisi ise kutsal kanona ait metinlerin katıksız bir şekilde gerçekten tarihsel ve otantik olup olmadığıydı. ${ }^{43} \mathrm{Bu}$ da ona, bu metinlerin tarihsel araştırmasına giden yolu açtı. Vardığı sonuç, asli Hıristiyanlık ile Kilise merkezli geleneksel Hıristiyanlık arasında önemli bir farkın olduğuydu. Bu ayrım, onu hem kutsal metin eleştirisine açık hale getirdi, hem de tüm bu eleştirel sonuçlara rağmen hala dindar kalabilmenin yolunu açtı.

Esasında bu görüşler, on sekizinci yüzyılın deistleriyle uyumludur ve onlardan ciddi etkiler taşır. Zira bu yüzyılda İngiltere'de deistler, kutsal metni bütünüyle reddeden bir teoloji de geliştirmemişlerdir. Daha ziyade onlar, idealize ettikleri bir tür asli Hıristiyanlık ile gelenek tarafından daha karmaşık hale getirilen Hıristiyanlık arasında birincisinden yana tavır almalarıyla öne çıkarlar. Böylece onlar, bir taraftan gelenek tarafından sonradan oluşturulmuş (buna kutsal metindeki değişikler de dâhildir) dogmatik önyargılar diye nitelendirdikleri şeylerin otoritesini kabul etmek gibi bir zorunluluktan kurtuldular; diğer taraftan ise kendi ‘doğal din' anlayışlarıyla ve rasyonel muhakemeleriyle uyumlu bir Hıristiyanlık inanışı geliştirmiş oldular. Vahiy kavramını kutsal metinden bağımsızlaştırmakla deistler, geleneksel dini metinlerin eleştirel araştırmasının yolunu iyice açtılar ve daha öncesinden antik metinler için uygulanan eleştirel prosedürleri kutsal metne de uyguladılar. Ayrıca kutsal metindeki akla aykırı olan şeyleri (bilhassa mucizeler) yeniden rasyonel zeminde yorumlamak için bir yol bulmuş oldular. İdealize edilmiş

42 Deistlerin bu tarz yorumlarına karşı hem Hıristiyan kitleden hem de Müslüman cenahtan yapılan eleştirilerin genel değerlendirmesi için bk. Mehmet Akif Altunışık, "Deizmin Meydan Okumalarına Karşı İslam Düşüncesinin Sorun Çözme Kabiliyeti: Yeni Bir Nübüvvet Teorisi Geliştirme Teklifi”, İslam ve Yorum II: Temel Tartışmalar, Imkânlar ve Sorunlar, yay. haz. Fikret Kahraman, ed. Mehmet Kubat vd. (Malatya: İnönü Üniversitesi Yayınları, 2018), 1:403-413.

43 Kümmel, The New Testament, 62-73; Scholtz, "The Phenomenon of 'Historicism', 80-81; Legaspi, The Death of Scripture, 129-154. 
bu asli Hıristiyanlığa yönelik olumlu ilgi, biblikal metinlerin tarihsel bağlamını ve yazarlarının niyetlerini bilmeye yönelik tarihsel-eleştirel bir ilgiyi tetiklemiştir. Böyle bir vahiy ve kutsal metin teolojisi, onların modern deistik din ve dindarlık anlayışlarıyla uyumludur. Bu genel tutum, John Toland (1670-1722) ${ }^{44}$, Matthew Tindal (1657173), Anthony Collins (1676-1729), Thomas Chubb (1679-1747), Thomas Morgan (ö. 1743) gibi deizminin popüler isimlerinde (aralarındaki bazı yorum farklılıklarına rağmen) görülebilir. Bunların her biri, on sekizinci yüzyılda tarihsel eleştirinin yükselişe geçtiği dönemlerde eleştirel çalışmaların ve buluşların önemli isimlerinden kabul edilmektedir. ${ }^{45}$ Tipkı deistler gibi Semler de Yeni Ahit metinlerini, öne çıkardığı bu asli Hıristiyanlığın tarihsel bağlamı içinde karşılaştırmalı rasyonel muhakemeler yoluyla değerlendirmeye çalışmışır. Söz konusu metinlerin yazarların niyetlerine odaklanan bir yorum modeli önermiştir. Bu yüzden onun yöntemi de tarihsel araştırmanın ilk örneklerinden kabul edilir.

Kabul etmek gerekir ki on sekizinci yüzyılın sonlarına kadar kutsal kitabın yorumuyla ilgilenen ilahiyatçların ve tarihçilerin bu uyum teolojilerine ve teşebbüslerine rağmen, yine de Kitab-1 Mukaddes eleştirisi on dokuzuncu yüzyılda daha radikal bir çizgiye doğru evrilmiştir. Seleflerinin açtıkları yolda, söz gelimi on sekizinci yüzyılda Almanya'da G. E. Lessing (1729-1781) ve H. S. Reimarius (1694-1768) on dokuzuncu yüzyılda ise liberal Protestan eleştirmenler, Kitab-1 Mukaddes'in geleneksel otoritesini sarsan ve geleneksel vahiy doktrinini yerinden eden daha radikal sonuçlara ulaştılar. F. C. Baur (1792-1860) ve D. F. Strauss'un (1808-1874) ve nihayet Wellhausen'in çalışmaları Kitab-ı Mukaddes ve Yahudi-Hıristiyanlık tarihine yönelik çalışmaları, söz konusu yaklaşımın on dokuzuncu yüzyılda geldiği önemli noktayı temsil eder.

\section{Sonuç}

Aydınlanmadan itibaren kutsal metne yönelik önce rasyonel muhakemelerle başlayıp daha sonra tarihsel araştırmalarla ilerleyen eleş-

\footnotetext{
44 Toland'ın vahiy ve mucize gibi konularda ortaya koyduğu eleştiriler hususunda detaylı bilgi için bk. Sait Kar, John Toland'ın Din Felsefesi (Saarbrücken: Lap Lambert Academic Publishing, 2017).

45 İngiliz deizmi ve kutsal metin eleştirisi ilişkisi hakkında bk. F. C. Conybeare, History of New Testament Criticism (London Watts \& Co., 1910), 30-48; Scholtz, "The Phenomenon of 'Historicism', 80-82; Kümmel, The New Testament, 51-61.
} 
tirel çalışmalar, öncelikle bu metinlerin otantikliği sorununu gündeme getirdiler. Bu yüzden tarihsel eleştirinin kutsal kitap araştırmalarında yükselişe geçişi ile bu metinlerin otoritesi sorunu arasında her zaman doğrudan bir bağ ve gerilim olmuştur. Hem eleştirel bilim taraftarları hem de muhafazakâr yönelimlere sahip olan diğer ilahiyatçlar, bu gerilimi aşmak için bir tür uyum ve arabuluculuk teolojileri geliştirmişlerdir. Çalışmamız boyunca tarihsel eleştirinin yükselişe geçtiği on yedinci ve on sekizinci yüzyılın önemli eleştirmenleri üzerinden göstermeye çalıştığımız üzere, dönemin eleştirmenlerinde ve ilahiyatçılarında büyük oranda benzer ilgiler öne çıkmaktadır. Reformasyon'dan miras aldıkları metnin literal anlamına yönelik olumlu ilgi; geleneğin göz ardı edilmesi; bu bağlamda doğal yasalarla uyumlu bir asli Hıristiyanlığın teşvik edilmesi; metinlerdeki doğaüstü anlatıların modern kültürle uyumlu bir şekilde rasyonel muhakemelerle yeniden yorumlanması; vahiy kavramının bu bağlamda yeniden inşa edilmesi ve kutsal metne bağlı olmaktan çıkarılması; böylece kutsal metnin öz ve kabuk şeklinde iki bölüme ayrılması; kutsal metin dışı kaynakların kutsal kitabın anlaşılmasında önemli bir kriter haline getirilmesi; daha önce antik metinler için uygulanan eleştirel prosedürlerin kutsal metinler için de uygulanabilir hale getirilmesi gibi bir çok faktör, esas itibariyle kutsal kitap eleştirisi ile onun otoritesi arasındaki gerilim sorununun bir parçası olarak işletilmiştir. Böylece onlar, bir taraftan eleştirel bilimin verileri kullandılar, fakat diğer taraftan kutsal metni bütünüyle reddetmek gibi radikal bir dönüşüm geçirmediler.

Öte yandan meseleye dair teolojik refleksiyon da buna paralel ilerlemiştir. Bilhassa on dokuzuncu yüzyıla gelindiğinde liberal ilahiyatçılar, kutsal metindeki anlatıları dogmanın açıklamaları yapmak yerine gittikçe tarihsel verilerin bir parçası haline dönüştürmüşlerdir. Hıristiyan teolojisi de bununla paralel bir şekilde tarihsel verinin bir parçası olarak yeniden tasarlanmıştır. On dokuzuncu yüzyılda geleneksel dogmatik ve sistematik teoloji karşısında bir tür biblikal-tarihsel teolojinin geliştirilmesi bu açıdan önem arz eder.

\section{Kaynakça}

Adam, A.K.M. Faithful Interpretation: Reading the Bible in a Postmodern World. Minneapolis: Fortress Press, 2006.

Altunışık, Mehmet Akif. “Deizmin Meydan Okumalarına Karşı İslam Düşüncesinin Sorun Çözme Kabiliyeti: Yeni Bir Nübüvvet Teorisi Ge- 
liştirme Teklifi". İslam ve Yorum II: Temel Tartışmalar, İmkânlar ve Sorunlar. Yayına hazırlayan Fikret Kahraman. Ed. Mehmet Kubat vd. 1:397-414. Malatya: İnönü Üniversitesi Yayınları, 2018.

Barr, James. Holy Scripture: Canon, Authority, Criticism. Oxford: Clarendon Press, 1983.

Barton, John. The Nature of Biblical Criticism. Louisville and London: Westminster John Knox Press, 2007.

Bravo, Benedetto. "Critice in the Sixteenth and Seventeenth Centuries and the Rise of the Notion of Historical Criticism". History of Scholarship. Ed. Christopher Ligota-Jean-Louis Quantin. 135-195. Oxford: Oxford University Press, 2006.

Capetz, Paul E. "Theology and the Historical-Critical Study of the Bible". The Harvard Theological Review 104/4 (2011): 459-488.

Childs, Brevard S. "The Sensus Literalis of Scripture: An Ancient and Modern Problem". Bieträge zur Alttestamentlichen Theologie. Ed. Herbert Donner vd. 80-93. Göttingen: Vandenhoeck \& Ruprecht, 1977.

Conybeare, F. C. History of New Testament Criticism. London: Watts \& Co. 1910.

Davids, Peter H. "Authority, Hermeneutics, and Criticism". New Testament Criticism and Interpretation. Ed. David Alan Black ve David S. Dockery. 2-21. Michigan: Zondervan Pub. House, 1991.

Duran, Asim. Aydınlanma ve Kutsal Kitap. Samsun: Üniversite Yayınları, 2017.

Fitzmyer, Joseph A. The Interpretation of Scripture: In Defense of the HistoricalCritical Method. New York: Paulist Press, 2008.

Gray, Edward McQueen. Old Testament Criticism: Its Rise and Progress, From Second Century to the End of the Eighteenth, A Historical Sketch. New York-London: Harper \& Brothers Publishers, 1923.

Grotius, Hugo. The Truth of the Christian Religion: In six Books. Corrected and Illustrated with Notes by Mr. Le Clerc, İngilizceye çeviren John Clarke, Eklemelerle on beşinci baskı. Oxford: Printed by W. Baxter, 1818.

Hardy, Nicholas. Criticism and Confession: The Bible in the Seventeeth Century Republic of Letters. Oxford: Oxford University Press, 2017.

Hayes, John H. \& Holladay, Carl R. Biblical Exegesis: A Beginner's Handbook. Gözden Geçirilmiş Baskı. Atlanta: John Knox Press, 1973.

Hays, Christopher M. "Towards a Faithful Criticism". Evangelical Faith and the Challenge of Historical Criticism. Eds. Christopher M. Hays ve Christopher B. Ansberry. 1-23. Grand Rapids: Baker Academic, 2013.

Jaroslav Pelikan, Historical Theology: Continuity and Change in Christian Doctrine (Eugene, Oregon: Wipf\&Stock, 2014).

Jenkins, Allan K. \& Preston, Patrick. Biblical Scholarship and the Church: A Sixteenth-Century Crisis of Authority. Ed. Allan K. Jenkins ve Patrick Preston. Hampshire: Ashgate, 2008. 
Jowett, Benjamin. "On the Interpretation of Scripture". Essays and Reviews. Ed. Frederick Temple vd. 330-433. London: John W. Parker and Son, 1860.

Kantzer, Kenneth S. "Evangelicals and the Doctrine of Inerrancy". The Foundation of Biblical Authority. Ed. James Montgomery Boice. 147-156. London-Glasgow: Pickering \& Inglis, 1979.

Kar, Sait. “Din, Aydınlanma ve Eleştirisi”. Atatürk Üniversitesi İlahiyat Fakültesi Dergisi 42 (2014): 173-192.

Kar, Sait. "Felsefi Açıdan İslamofobi ve Eleştirisi". Ilahiyat Tetkikleri Dergisi (ILTED). 47 (2017): 199-222.

Kar, Sait. John Toland'ın Din Felsefesi. Saarbrücken: Lap Lambert Academic Publishing, 2017.

Knight, Douglas A. Rediscovering the Traditions of Israel. Third Edition. Atlanta: Society of Biblical Literature, 2006.

Kolp, Robert. "The Bible in the Reformation and Protestant Orthodoxy". The Enduring Authority of the Christian Scriptures. Ed. D. A. Carson. 89114. Grand Rapids/Cambridge: Wm. B. Eerdmans Publishing Co., 2016.

Kümmel, Werner Georg. The New Testament: The History of the Investigation of Its Problems. İngilizceye çeviren S. McLean Gilmour \& Howard C. Kee. Nashville: Abingdon Press, 1972.

Lee, Michael J. The Erosion of Biblical Certainty: Battles over Authority and Interpretation in America. New York: Palgrave Macmillan, 2013.

Legaspi, Michael C. The Death of Scripture and the Rise of Biblical Studies. Oxford: Oxford University Press, 2010.

Linnemann, Eta. "Historical-Critical Theology and Evangelical Theory". Journal of the Adventist Theological Society 5/2 (Bahar 1994): 19-36.

Maier, Gerhard. The End of the Historical-Critical Method. St. Louis: Concordia Publishing House, 1977.

McGrath, Alister E. Historical Theology: An Introduction to the History of Christian Thought. İkinci basım. Malden, MA: Wiley-Blackwell, 2013.

Morgan, Robert \& Barton, John. Biblical Interpretation. Oxford: Oxford University Press, 1988.

Nash, Henry S. The History of the Higher Criticism of the New Testament. New York: The Macmillan Company, 1900.

Noll, Mark A. Between Faith and Criticism: Evangelicals, Scholarship, and the Bible in America. Vancouver: Regent College Publishing, 2004.

Price, Robert M. Inerrant the Wind: Evangelical Crisis of Biblical Authority. Amherst, New York: Prometheus Books, 2009.

Richardson, Alan. "The Rise of Modern Biblical Scholarship and Recent Discussion of the Authority of the Bible". The Cambridge History of the Bible: The West from the Reformation to the Present Day. Ed. S. L. Greenslade. 294-338. Cambridge: Cambridge University Press, 1976. 
Rogerson, John W. "Historical Criticism and the Authority of the Bible". The Oxford Handbook of Biblical Studies. Ed. J. W. Rogerson ve Juddith M. Lieu. 841-859. Oxford: Oxford University Press, 2006.

Scholtz, Gunter. "The Phenomenon of 'Historicism' as a Backcloth of Biblical Scholarship". Hebrew Bible/Old Testament: The History of Its Interpretation, III/1: Nineteenth Century. Ed. Magne Sæbø. III/1:64-89. Vandenhoeck \&Ruprecht, Göttingen 2013.

Simon, Richard. A Critical History of the Old Testament. London: Walter Davis, 1682.

Sparks, Kenton L. God's Word in Human Words: An Evangelical Appropriation of Critical Biblical Scholarship. Grand Rapids: Baker Academic, 2008.

Steiger, Johann Anselm. "The Develepment of the Reformatin Legacy". Hebrew Bible Old Testament: The Histoy of Its Interperetaion. Ed. Magne Sæbø. II/691-757. Göttingen: Vandenhoeck \& Ruprecht, 2008.

Tatar, Burhanettin. "Kur'ân'1 Yorumlama Sorunu". Kur'an ve Dil: Dilbilim ve Hermenötik Sempozyumu Bildirileri (Van, 17-18 Mayıs 2001). Ed. Necati Kara. 493-508. Erzurum: Bakanlar Matbaası, 2001.

Tatar, Burhanettin. "Kutsal Metin ve Otorite: Tarihsel-Fenomenolojik Bir Analiz". Milel ve Nihal 14/1 (2017): 64-76.

The Confession of Faith of the Assembly of Divines at Westminster. Ed. S. W. Carruthers. London: Publishing Office of the Presbyterian Church of England, 1946.

van den Belt, Henk. The Authority of Scripture in Reformed Theology: Truth and Trust. Leiden, Boston: Brill, 2008.

van Vlastuin, Willem. “Sola Scriptura: The Relevance of Luther's Use of Sola Scriptura in De Servo Arbitrio". Sola Scriptura: Biblical and Theological Perspectives on Scripture, Authority, and Hermeneutics. Ed. Hans Burger vd. 243-259. Leiden, Boston: Brill, 2018.

Wright, N. T. "How Can the Bible Be Authoritative? (The Laing Lecture for 1989)". Vox Evangelica 21 (1991): 7-32. 